\title{
PECULIARITIES OF POLITICAL RATIONALITY IN POSTMODERNISM
}

\author{
Lidiia Tokarieva \\ Podtgraduate Student at the Department of Theory and History of Political Science, \\ Ivan Franko National University of Lviv, Ukraine \\ e-mail: lidagendalf13@gmail.com,orcid.org/0000-0002-6161-6859
}

\section{Summary}

In the second half of the twentieth century, the debate intensified that the excessive rationalism of modernism in fact doomed political science to forced self-isolation, the utopian search for root causes, clear interdisciplinary boundaries that would become "monotheistic social orientations." Once again there is a controversy about the destructive role of rationalism in political theory and practice, the universalization of common ideals. This article considers the phenomenon of postmodernism. As well as the comprehension the nature of the political from the standpoint of different types of political rationality and the main vectors of its development in postmodern political thought. Proponents of the postmodern approach believe that the ideal of total rationality does not correspond to the spirit of humanism, the absolutization of rationalism brings with it the dehumanization of the individual, is a source of global dangers, risks, threats to humanity. From the point of view of postmodernism in the modern era there was no awareness of the absence of structure, and therefore it is permeated with the ideals of general structural organization, the spirit of rationalism, rationalist criticism, the search for common ground, doubt, the atmosphere of resistance.

Keywords: postmodernism, rationality, political rationality, anti-scientism, global political rationality, local political rationality

DOI: https://doi.org/10.23856/3839

\section{Introduction}

Postmodernism and structuralism are called one of the most ambiguous and influential ideas of the last century, influential in many areas of scientific research, so it was especially evident in philosophy and the humanities (including research political science). Proponents and opponents for a long time continued debates about the position of postmodernism, especially in matters of rationality. Critics of postmodernism saw it as a kind of attack on rationality, which should be rejected as an attempt to distort the mind. At the same time, proponents of postmodernism saw it as a powerful critique of Western scientific traditions. Especially those aspects of political rationality that express hidden dictatorial relations that cannot themselves be based on any rational principles.

Today, postmodernism is seen as a new vector in political theory. It explains phenomena and processes in the political plane and form the so-called "postmodern" reality in the manner of post-industrial, postmodern society. Also it has to identify strategies, goals and objectives of human development in historical perspective, because the philosophical ideal of Modernism wasdetected as the unsuitable in this situation. The aim of this article is to study the phenomenon of political rationality in postmodern discourse and to identify a range of interpretations of political rationality in postmodern discourses and to outline the main features and issues of rationality methodology in postmodern discourse (Grobber A., 1990: 494). 
According to the goal, the research task is to consider the evolution of political rationality in postmodern discourse, analyze the problems of political rationality, determine the structure of the invariant idea ofpolitical rationality and, based on the proposed structure, identify a scheme of typology of political rationality.

This work is based on the method of analysis of the structure of rationality to the specifics of political rationality in postmodern discourses, which ensures its internal unity. In addition, the principles and methods of historicism, objectivity, specificity, unity of historical and logical were used. At certain stages of the study, methods of semantic and comparative analysis were used.

\section{The problem of political rationality in postmodern conditions}

The crisis of the rationalist worldview of the Western world determines the need for a comprehensive critical study of modern processes of derationalization and irrationalization of politics, which are becoming a reality today.

One of the main drivers of these processes can be considered postmodernism, which is strongly influenced by political thought of the late twentieth century, including domestic. In such circumstances, the very foundations of this theoretical direction remain critically identified and unanalyzed, which often leads to incorrect assessments and interpretations. Another problem is the still unexplained efficiency and validity of the use of "postmodern" theories for political science analysis (Alekseeva E.A, 1991: 32).

A number of researchers, including Z. Baumann, R. Inglehart, J.-F. Lyotard, M. Heidegger, have studied the phenomenon of postmodernism from different positions and note its manifestations in politics, economics, art and technology. In particular, Z. Bauman, D. Bell and J. Habermas interpret postmodernism as a result of the interaction of politics and ideology of neoconservatism, which is characterized by aesthetic eclecticism, fetishization of consumer goods and other characteristics of post-industrial society (Liotar Zh.-F., 1998: 124).

The effectiveness of rationality is recognized by all - philosophers, scientists of various specialties, psychologists, teachers, managers and others. Rationality provides an uninterrupted process of cognition of being, however, here it also reveals its limitations (Porus V. N., 1995: 49). This phenomenon was later defined as irrationalism, intuitionism, but received its justification only at the stage of non-classical and post-classical cognition. The question of how new knowledge arises, how the transition from feelings to concepts and from concepts to feelings, is one of the main in epistemology and philosophy of science.

Postmodernism is characterized by "distrust of metanarratives" (J.-F. Lyotard) and the rejection of the "vertical" dimension of existence. This leads to a rethinking of traditional for classical rationality "binary oppositions", the elimination of the dualism of being / thinking, subject / object paradigm, the rejection of "centrism", "chaos" of "space" and solving the problem of "gap" between being and thinking by bringing together the "world of things" and the "world of ideas" of comprehension in one plane (Liotar Zh.-F., 1998: 69).

Theorists of science give different interpretations of ways and methods of obtaining new knowledge, however, no matter what innovative methods of cognition resorted to postmodernism, it is worth remembering that any new knowledge is based on traditional ways of understanding reality. Thus, along with the rational characteristics of scientific knowledge, philosophers are interested in the irrational sphere of scientific research.

Despite the challenge posed by postmodernism to the traditional understanding of rationality, postmodernist political philosophy, both implicit and explicit, contains positive 
conceptions of the "new rationality." Representatives of postmodern philosophical and political thought are looking for a way to break through "on the other side" of already known, to completely new knowledge.

Postmodernist discourse thus seeks to go beyond the meanings conditioned by classical metanarratives and to include in the "new rationality" the whole plurality of the spectrum of branched marginal meanings, in a way to "chaotize" existing structures of rational thinking and emphasize the "moment of paradox" entailing the abandonment of all forms of fundamentalist monism in favor of pluralism (Rutmanis K.V., 1995: 30).

Thus, we can generalize that postmodernists consider the structure of language as capable of independent development, the space of opportunities for philosophical experimentation. Today, the main task, even for "orthodox" - rationalist-oriented researchers of political discourse, should not be a total denial of postmodernist "discourses" and sometimes and sometimes quite original "philosophical experiments" on language structures, but, above all, an attempt to clarify opportunities for "new rationality", "pluralism", "plurality". In other words, the critique of postmodernism, in our view, must be a rationalist critique in the Kantian sense of the word: a critique as the setting of new limits to the possibilities of reason in a world that is constantly out of the control of that very mind.

Within the scientific discourse, it is impossible to recognize the truth, the rationality of one point of view over others. In the case of the dominance of one position, its supremacy is based not on the power of truth, but on charisma, power or authority. However, postmodernism, as once empiricism, and later positivism, opposes any conceptual systems and interdependent determinations, resulting in political life appears as a variety of nuances, differences and individual characteristics, in which everything is equal. Postmodernism replaces science with "scientificity", which does not require rigor, accuracy, predictability, provability, because nothing new can be created, all truths have already been obtained and all mistakes have already been made.

Postmodernism offers an expanded understanding of political rationality, which includes even its irrational and anti-rational forms based on principled plurality and pluralism, and therefore requires an emphasis on "erudition" as a way of understanding this plurality.

\section{Features of global and local dimensions of political rationality}

In order to interpret the concept of political rationality taking into account its global and local features, it is necessary to take into account a number of important factors.

- the paradigm of the rational is based on aggregate experience;

- rational, including political, must be considered in the dynamics: the change of activity naturally changes the meaning of the rational, so the rational in some situations may lose this characteristic in other situations;

- rationality combines efficiency, optimality, method of certain activities. Only by complying with the above characteristics can we predict the achievement of the goal with a minimum amount of losses;

- characteristics of the rational is manifested by assessing the activities and their compliance with the fundamental laws of social and political development. In the case of setting an inadequate goal and appropriate means - we get a distorted rationality (Il'in I.P., 1998: 42).

In the local dimension, political rationality is interpreted as an activity aimed at achievingreal (adequate) goals. Thus, the local interpretation of political rationality occurs in the case of taking into account the situational characteristics of the goal and related activities. 
In global interpretations of political rationality, it is interpreted as an activity based on practical principles and principles that do not contradict public goals. Global interpretations of political rationality take into account relatively universal socio-political constants.

\section{Types of political rationality in postmodernism}

Postmodernism tells us about the variety of types of rationalism. There are actually many of them, but this does not mean that they are segregated, isolated from each other, in opposition, not connected by any laws and connections. All types of rationality are connected, to some extent even imitate each other, however transitions between them are presented by qualitatively different types of communications and relations. That is why the characteristic continuity between different types of rationality is qualitatively different. Therefore, the transition to the study and development of new types of political rationality, the development of new types of political consciousness and behavior, requires a long time and serious socio-political changes.

Thus, the variety of types and forms of rationality does not reject rationality as the general ability of human thought to master the qualitatively diverse structural connections and relations of existence. To reflect each type of structural organization in the consciousness of the subject, it is necessary to form a certain type of rationality. That is why the structure of the political acts as a layering of historical types of rationality, so it is important to remember that these historical layers never disappear completely (Gurevich P.S., 1995: 34).

The lower structures represented by the earlier historical forms of consciousness and the corresponding types of rationality do not die out, but become subordinate structures of higher forms of consciousness and rationality, changing their basic functions and obeying the needs of the higher system. Rejecting the heredity of types of rationality, postmodernism creates an obstacle to understanding that structure still exists.

\section{Postmodernism and anti-nationalist approach to the understanding of political}

In the XX-XXI centuries. rational understanding of the political goes beyond philosophical and theoretical discourses, and becomes a real cause of existential concern, more and more often there are theses that the ideals of rationality are incommensurable with the guarantees of the future of civilization. Rationalism has become perceived as part of those crisis circumstances that can contribute to large-scale political crises, up to military conflicts and revolutions. At the head of such an anti-rationalist movement is postmodernism, which claims the role of a theory of philosophical doubt in the strength of the ideals of politics, its absolutes. Postmodern critique of rationalism comes from the critique of the methodology and ontology of structuralism (especially French), the central concept of which was the concept of structure.

Postmodernism claims that there is no rationality that is universal for all. one for all. There is no metaphysical, obligatory and generally acceptable solution to the problem of rationality. From the point of view of postmodernism, it is time to abandon all attempts to create a universal paradigm of rationality: such a paradigm does not exist and can not exist, each historical epoch is characterized by a special type of rationality (including political). There is no universal rationality, there is only a set of unrelated rationalities, as understood by the representatives of a particular social community.

Rationality is a phenomenon of consciousness, impossible, on the one hand, without intuition and imagination; and on the other - without analytical, discursive, orderly, normative and systematic. Thus, any rational discovery always destroys the established canons and 
creates new ones, which will also inevitably be destroyed in the course of the historical development of society.

The current government often uses the lack of sound management for its own purposes, allowing political reactors to make their own decisions, play by their own rules and, as a result, blame themselves for political failures and take responsibility if the result does not live up to expectations. The more people involved in the political process feel uncomfortable, exposed to insurance (often anti- or irrational), the more influential the state feels in this situation, being able to manipulate them. In such conditions, a person does not lose the ability to think in terms of past and future, only the concept of "here and now" comes to the fore, which revolves around one's own "I", not allowing him to abstract, look at the process or situation from the side and analyze events.

\section{Conclusions}

The theoretical and practical significance of the article is an attempt to rethink the problem and methodology of political rationality in the context of modern Western philosophy. In addition, the conclusions and main theses can be used in the development of special courses, elective classes, become the basis of scientific conferences and round tables, serve as the basis of monographs and scientific papers. Also, the main provisions presented in the paper can be used in the further analysis of epistemological and methodological problems of both scientific forms of political rationality and its non-scientific forms.

During the study we were able to draw the following conclusions:

1) The formation of new methodological approaches in the philosophy of politics to the phenomena of socio-political life is an urgent need of society;

2) Political rationality as a scientific problem is implicitly present at different stages of social development in those forms that were set by specific ways of its formulation and solution depending on the context of the era and the internal logic of its development;

3) Historical types of rationality change due to changes in the socio-cultural context within which they exist and function. These changes are gradual, and we can talk about the continuity of historical types of rationality and the continuous process of development of rationality. Conceptual and conceptual analysis of political ideologies allows us to say that the latter are derived from a specific type of rationality, namely - the type of rationality of the New Age;

4) Analysis of political processes in modern society (including Ukrainian), shows a steady trend towards the formation of a holistic political field, which allows to use in assessing the prospects of its development not only classical approaches but also methodological techniques of non-classical and post-classical types of rationality, each of which is an additional description system.

\section{References}

Alekseeva E. A. (1991). Racional'nost' i soznanie: istoriko-teoreticheskij ocherk problem osnovaniya racional'nosti [Rationality and consciousness: a historical and theoretical sketch of the problems of the foundation of rationality]. Minsk: Nauka i tekhnika. [in Russian]. Gurevich P. S. (1995). Poisk novoj racional'nosti (po materialam trekh vsemirnyh kongressov) // Racional'nost' kak predmet filosofskogo issledovaniya [Search for a new rationality (according to the materials of three world congresses) // Rationality as a subject of philosophical research]. M.: IFRAN. [in Russian]. 
Grobber A. (1990). Between Rationalism and Relativism. On Larry Laudan's Model of Scientific Rationality. The British Journal for the Philosophy of Science. № 4, 493-507.

Il'in I. P. (1998). Postmodernizm ot istokov do konca stoletiya: evolyuciya nauchnogo mifa [Postmodernism from its origins to the end of the century: the evolution of the scientific myth]. M.: Intrada. [in Russian].

Krige J. (1998). Science, Revolution and Discontinuity. Brighton: Harvester Press.

Liotar Zh.-F. (1998). Sostoyanie postmoderna [The state of postmodernism]. M.: Institute of Experimental Sociology. [in Russian].

Porus V. N. (1995). Sistemnyj smysl ponyatiya "nauchnaya real'nost'”. Racional'nost' kak predmet filosofskogo issledovaniya [Systemic meaning of the concept of "scientific reality". Rationality as a subject of philosophical research]. M.: IFRAN. [in Russian].

Rutmanis K. V. (1995). Genezis idej racional'nosti v filosofii. Racional'nost' kak predmet filosofskogo issledovaniya [Genesis of ideas of rationality in philosophy. Rationality as a subject of philosophical research]. M.: IFRAN. [in Russian]. 